Ferguson, J. 1970: The significance of the kakortokite in the evolution of the llimaussaq intrusion, South Greenland. Bull. Grønlands geol. Unders. 89 (also Meddr Grønland 190, 1), 193 pp.

Institut for Petrologi, University of Copenhagen,

$\emptyset$ ster Voldgade 10,

1350 København $K$.

\title{
Preliminary geochemical work on the Ilímaussaq alkaline intrusion, South Greenland
}

\section{John Bailey, Raymond Gwozdz, John Rose-Hansen and Henning Sørensen}

As part of the geological investigation of the Ilímaussaq intrusion (Sørensen, 1970; Ferguson, 1964; Andersen, et al., 1973; Sørensen et al., 1974), trace-element analyses have been performed on carefully chosen rock samples. Material was selected on the basis of detailed field mapping and with particular attention paid to its fresh and representative nature; in every case more than $15 \mathrm{~kg}$ was obtained by blasting. The samples have already been used for the separation of accessory ore minerals and for analysis of fluid inclusions.

To date, the rocks have been analysed for trace elements by neutron activation (R.G.) and $\mathrm{X}$-ray fluorescence (J.B.) analysis. Comparisons with earlier analytical results indicate closest agreement with the work of Gerasimovsky (1969), except for the element Ga where his results are consistently higher. Experiments by Ib Sørensen (GGU Chemical Laboratory) indicate that fused samples yield low totals for many Ilímaussaq rocks; the absorption effects of heavy minor elements $(\mathrm{Zr}, \mathrm{Nb}, \mathrm{REE})$ on the light major elements will be quantitatively corrected for. Analyses by isotope fluorescence, delayed neutron analysis, $\mathrm{X}$-ray spectrometry and other techniques are in progress.

Average trace-element analyses are presented for seven agpaitic rocks types from the Ilímaussaq intrusion in Table 3; sample localities are indicated in figure 25 .

The alkali elements ( $\mathrm{Rb}, \mathrm{Cs})$ typically occur at high levels and the rocks exhibit low $\mathrm{K} / \mathrm{Rb}$ and $\mathrm{K} / \mathrm{Cs}$ ratios. These tendencies become more pronounced in the final lujavrite differentiates.

$\mathrm{Sr}$ and $\mathrm{Eu}^{2+}$ are considered to be largely removed in the early stages of fractionation by feldspars. In the agpaitic rocks, they mainly enter eudialyte.

Rare-earth elements (REE, La-Lu, Y) reach exceptionally high levels in the eudialyte-rich kakortokites, and in the final lujavrites where a number of REE minerals are developed. In earlier agpaites (sodalite-bearing foyaite and naujaite, kakortokites), REE contents correlate with $\mathrm{Zr}$ and the REE are mainly located in eudialyte. Whole-rock REE spectra (fig. 27) reveal (a) a general increase in total REE, (b) increase in light REE/heavy $\mathrm{REE}$ in the lujavrites and (c) a more or less uniformly negative Eu anomaly. 
Table 3. Average (median) trace-element contents for agpaitic rocks from the Ilimaussaq alkaline intrusion, South Greenland (in ppm)

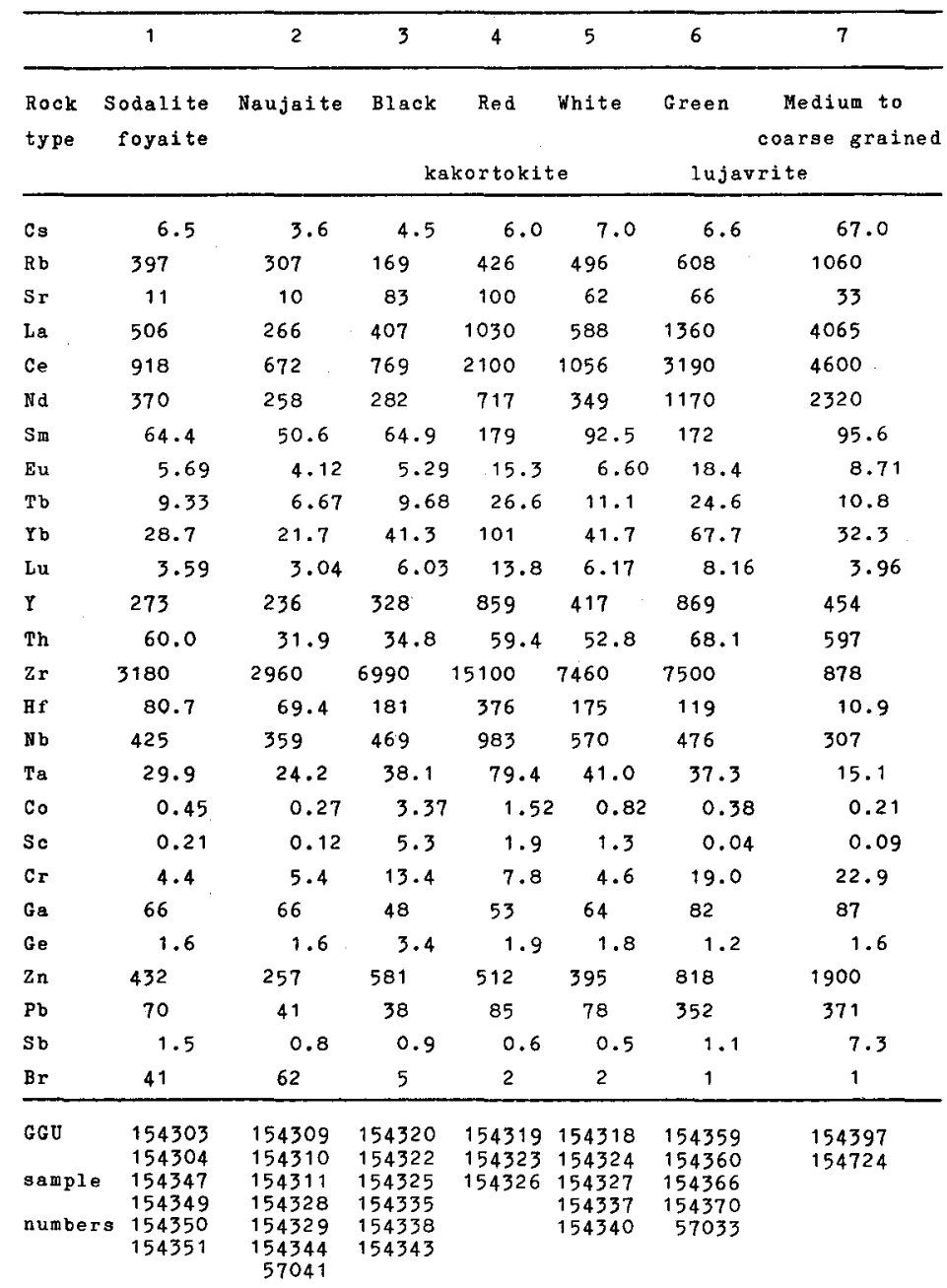

The large highly charged cations ( $\mathrm{Zr}, \mathrm{Hf}, \mathrm{Nb}, \mathrm{Ta}, \mathrm{Th}$ ) reach abnormally high levels of concentration. $\mathrm{Zr}, \mathrm{Hf}, \mathrm{Nb}$ and $\mathrm{Ta}$ contents are maximal at the kakortokite stage but $\mathrm{Th}$ continues to increase throughout the final lujavrites. There is an increase in the $\mathrm{Zr} / \mathrm{Hf}$ (from about 40 to 80 ) and $\mathrm{Nb} / \mathrm{Ta}$ (from about 13 to 20 ) ratios in the late lujavrites.

Of the transition metals, $\mathrm{Zn}$ and to some extent $\mathrm{Cr}$ are concentrated in the final agpaites but $\mathrm{Sc}$ and $\mathrm{Co}$ show their highest concentrations in black kakortokite. $\mathrm{Zn}$ enters arfvedsonite but in addition it exhibits marked chalcophile properties and along with $\mathrm{Pb}$ and $\mathrm{Sb}$ attains notably high concentrations in the final lujavrites. 
Fig. 27. Rare-earth element patterns for selected rocks from the Ilímaussaq alkaline intrusion. Only last two figures of full GGU sample number given e.g. (154319).

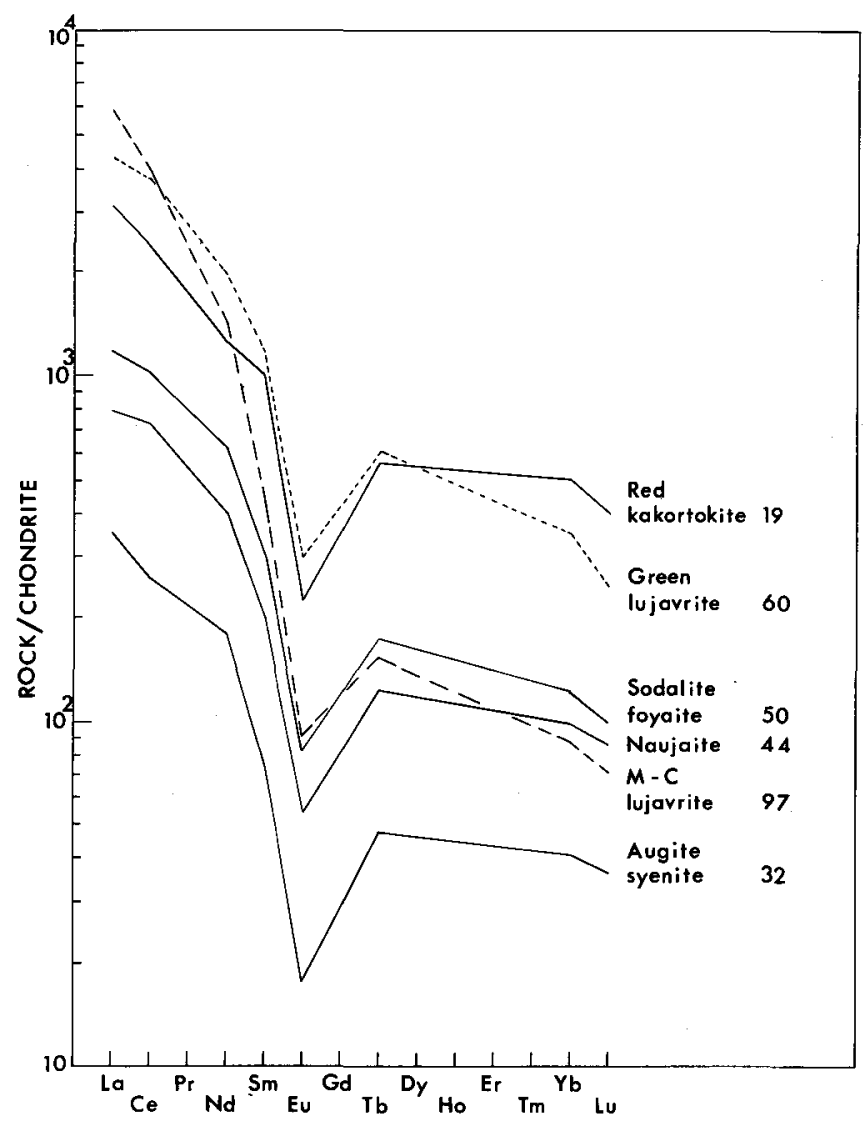

Ge tends to be preferentially incorporated in the black kakortokite and presumably enters arfvedsonite; absolute contents are comparable with other igneous rocks. Ga maintains high levels in the agpaitic rocks, particularly the late lujavrites.

High $\mathrm{Br}$ contents occur in the sodalite-rich (Cl-rich) foyaites and naujaites but decrease sharply in the sodalite-poor kakortokites and lujavrites.

Table 4 compares the geochemistry of lujavrites from the llimaussaq intrusion with those from Lovozero (Kola, USSR) and Pilanesberg (South Africa). All these rocks are characterised by high contents of 'residual' trace elements and by fractionated element ratios. The Ilímaussaq lujavrites are generally the most extreme of the three localities in this respect. The Fe-rich oversaturated peralkaline lavas (pantellerites) share many of the extreme geochemical features shown by the Fe-rich undersaturated lujavrites.

Future work will extend the multi-element analysis of llímaussaq rocks and minerals, and integrate the results with the physical-chemical history of the intrusion. Geochemical work will also supplement the increasingly detailed mapping of the intrusion, and continue to provide basic information for economic assessment of the intrusion. 
Table 4. Geochemical indices for lujavrites of the Ilimaussaq alkaline intrusion, with comparisons

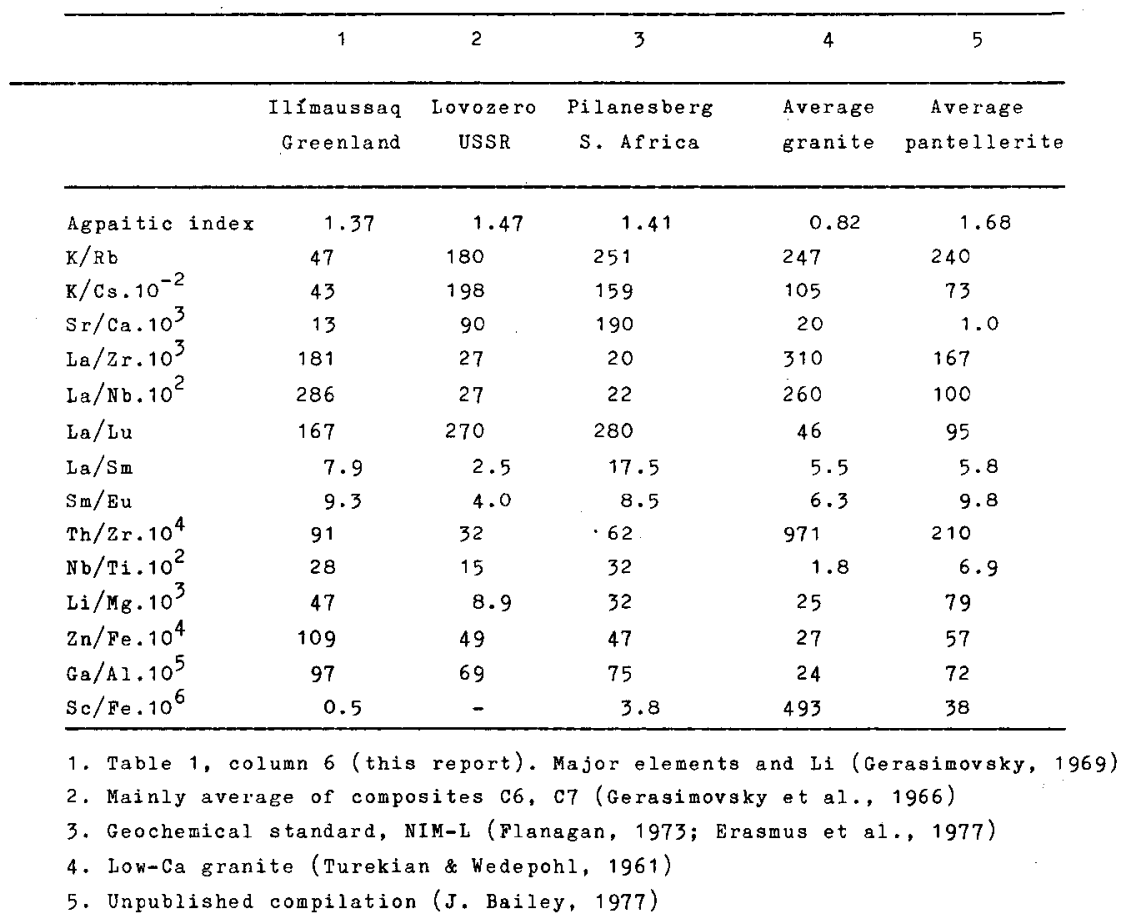

\section{Acknowledgement}

The Danish Natural Science Research Council (SNF) supported the neutron activation and X-ray fluorescence analytical programmes.

\section{References}

Andersen, S., Bailey, J., Karup-Møller, S., Løkkegaard, L., Rose-Hansen, J., Steenfelt, A. \& Sørensen, H. 1973: Research projects on the Ilimaussaq alkaline intrusion, South Greenland. Rapp. Grønlands geol. Unders. 55, 38-40.

Erasmus, C. S., Fesq, H. W., Kable, E. J. D., Rasmussen, S. E. \& Sellschop, J. P. F. 1977: The NIMROC samples as reference materials for neutron activation analysis. Radioanalyt. Chem. 39, 323-334.

Ferguson, J. 1964: Geology of the Ilímaussaq alkaline intrusion. South Greenland. Description of map and structure. Bull. Grønlands geol. Unders. 39 (also Meddr Grønland 172, 4) $82 \mathrm{pp}$.

Flanagan, F. J. 1973: 1972 values for international geochemical reference samples. Geochim. Cosmochim. Acta 37, 1189-1200.

Gerasimovsky, V. I. 1969: Geochemistry of the Ilimaussaq alkaline massif (South-West Greenland) (in Russian). Moskva: Nauka, $174 \mathrm{pp}$. 
Gerasimovsky, V. I., Volkov, V. P., Kogarko, L. N., Polyakov, A. I., Saprykina, T. V. \& Balashov, Yu.A. 1966: The Geochemistry of the Lovozero Alkaline Massif, Pt. II (in Russian). Moskva: Nauka, 149-396.

Sørensen, H. 1970: Internal structures and geological setting of the three agpaitic intrusions - Khibina and Lovozero of the Kola Peninsula and Ilímaussaq, South Greenland. Can. Mineral. 10, 3, 299-334.

Sørensen, H., Rose-Hansen, J., Nielsen, B. L., Løvborg, L., Sørensen, E. \& Lundgaard, T. 1974: The uranium deposit at Kvanefjeld, the Ilímaussaq intrusion, South Greenland. Geology, reserves and beneficiation. Rapp. Grønlands geol. Unders. 60, $54 \mathrm{pp}$.

Turekian, K. K. \& Wedepohl, K. H. 1961: Distribution of elements in some major units of the Earth's crust. Bull. geol. Soc. Amer. 72, 175-192.

Institut for Petrologi, University of Copenhagen,

$\emptyset$ ster Voldgade 10,

1350 Copenhagen $K$.

\section{High zinc contents of sea water in Kangerdluarssuk, the Ilímaussaq area, South Greenland}

\section{Gert Asmund and John Rose-Hansen}

Samples of sea water were collected in Kangerdluarssuk in the summers of 1974 and 1975 (fig. 28) as part of the geochemical-ecological Narssaq project (Bohse et al., 1975; Nielsen et al., 1976). These have been analysed for dissolved zinc, cadmium, lead and copper by anodic

Fig. 28. Sketch map of the head of Kangerdluarssuk, South Greenland, showing positions of the analysed sea water samples discussed by Asmund \& Rose-Hansen.

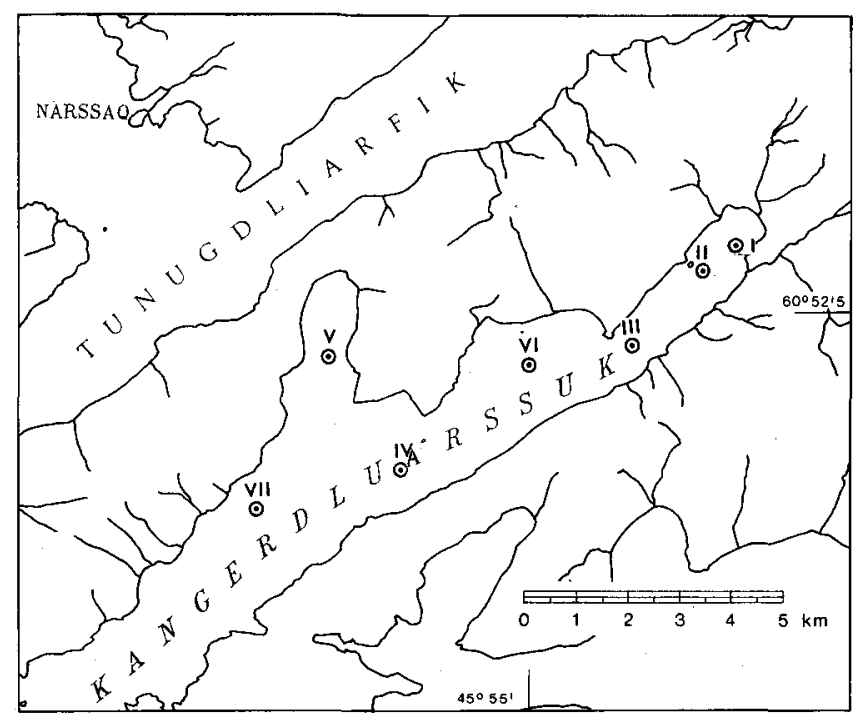

